\title{
Some Observations on Tie-ins, the Single-Product Defense, Exclusive Dealing and Regulated Industries
}

\author{
Malcolm E. Wheeler*
}

Per se rules in antitrust law allegedly enable the courts to dispose of large groups of cases without having to examine voluminous data and choose between conflicting sophisticated and abstruse economic theories. ${ }^{1}$ Seldom, however, do per se rules effectuate that purpose. Rather, they usually simply shift the focus of the court's initial scrutiny from the basic issue of whether trade has been or is likely to be restrained to the definitional question of whether the challenged practice is a boycott, ${ }^{2}$ a price fixing schene, ${ }^{3}$ a horizontal market division, ${ }^{4}$ or a tie-in. ${ }^{5}$ Furthermore, as the Supreme Court demonstrated in United States v. Jerrold Electronics Corp. ${ }^{6}$ even if the court decides the challenged practice is encompassed by one of the talismanic terms, it may still face the basic issue and hold for the defendant on the ground that the practice in the particular instance furthered, rather than hindered, competition.

This through-the-looking-glass approach reached what inust surely be its pinnacle in Washington Gas Light Co. v. Virginia Electric \&

* Associate Professor of Law, University of Kansas. S.B. 1966, Massachusetts Institute of Technology; J.D. 1969, Stanford University. Research for this article was supported in part by a General Research Grant from the University of Kansas.

1. See United States v. Topco Associates, Inc., 405 U.S. 596, 607 (1972); Northern Pac. Ry. v. Umited States, 356 U.S. 1, 5 (1958). See generally Bork, The Rule of Reason and the Per se Concept, 74 YALE L.J. 775 (1965). (1925).

2. See, e.g., Cement Mfrs. Protective Ass'n v. United States, 268 U.S. 588

3. See, e.g., Theatre Enterprises, Inc. v. Paranount Film Distrib. Corp., 346 U.S. 537 (1954); Maple Flooring Mfrs. Ass'n v. United States, 268 U.S. 563 (1925); Chicago Bd. of Trade v. United States, 246 U.S. 231 (1918). But cf. United States v. Topco Associates, Inc., 405 U.S. 596 (1972).

4. Cf. White Motor Co. v. United States, 372 U.S. 253 (1963); United States v. Pan American World Airways, Inc., 193 F. Supp. 18 (S.D.N.Y. 1961), rev'd on other grounds, 371 U.S. 296 (1963). But see United States v. Topco Associates, Inc., 405 U.S. 596 (1972).

5. See Umited States v. Jerrold Electronics Corp., 187 F. Supp. 545 (E.D. Pa. 1960), aff'd per curiam, 365 U.S. 567 (1961); Times-Picayune Publishing Co. v. United States, 345 U.S. 594 (1953).

6. 187 F. Supp. 545 (E.D. Pa. 1960), aff'd per curiam, 365 U.S. 567 (1961). 
Power Co., ${ }^{7}$ a recent case before the Court of Appeals for the Fourth Circuit. The Virginia Electric \& Power Company (VEPCO) offered as a promotional scheme to reduce or waive the charge for installing underground power lines (URD, for underground residential distribution) for builders who agreed to build all-electric or substantially allelectric units. Because the scheme was a great success, Washington Gas Light Company's sales of gas for water heating, space heating, cooking, and clothes drying decreased alarmingly. It sued, alleging, inter alia, that VEPCO's scheme constituted a tying arrangement in violation of section one of the Sherman Act. ${ }^{8}$ The district court held for the plaintiff, ${ }^{9}$ but the court of appeals reversed, holding that there could be no tie-m because there was but a single product: electricity. ${ }^{10}$

The case was rife with errors at every conceivable level: analysis of the single-product defense to tie-in charges, determination of the tied and tying products, and analysis of substantive tie-in law. This Article examines and criticizes the VEPCO decision, not only to denonstrate some of the typical problems which continue to befuddle the courts in tie-in cases but also to delineate more clearly the boundaries of the tie-m doctrine and the single-product defense. Concomitantly, it suggests some problem areas that regulatory agencies should scrutinize but presently tend to disregard. The task begins with a brief review of tie-ins and the single-product defense.

\section{I}

\section{Tie-Ins AND the Single-Product Defense}

Generally, tie-ins are transactions in which a seller agrees to sell $\mathrm{X}$, the tying product, only if the purchaser also agrees to purchase some

7. 438 F.2d 248 (4th Cir. 1971).

8. .15 U.S.C. $\$ 1$ (1970). The complaint also alleged an exclusive dealing arrangement im violation of section three of the Clayton Act. Id. $\$ 14$.

9. Washington Gas Light Co. v. Virginia Elec. \& Power Co., 309 F. Supp. 1119 (E.D. Va. 1970). The district court found violations of both section one of the Sherman Act and section three of the Clayton Act.

10. The court offered an alternative ground for reversal, holding that the Virginia State Corporation Commission's regulatory power over the defendant exempted the challenged conduct from the antitrust laws because of the state-action doctrine articulated in Parker v. Brown, 317 U.S. 341 (1943). An excellent discussion of the court's treatment of this issue can be found in 85 HaRv. L. Rev. 670 (1972). See generally Handler, Twenty-Fourth Annual Antitrust Review, 72 Colum. L. Rev. 1, 4-18 (1972).

Strangely, the court failed to mention the district court's alternative holding that VEPCO had violated section three of the Clayton Act with an exclusive dealing arrangement. Although this omission can be explamed by the fact that the state-action exemption covers both tie-in and exclusive dealing violations, it is curious that the court felt compelled to address the tie-in issue but not the exclusive dealing issue. In any event, it is clear that the court erred im stating of the state-action exemption and the tying issue, "[e]ither . . . may be decisive of the appeal." 438 F.2d at 249. 
quantity of $Y$, the tied product. ${ }^{11}$ The term is also used to describe situations in which a seller fixes a high price on $X$ if bought alone and a lower price on $\mathrm{X}$ if bought with $\mathrm{Y}$, where the price difference cannot be accounted for by economies of joint production or marketing. ${ }^{12}$

11. See generally Bowman, Tying Arrangements and the Leverage Problem, 67 Yale L.J. 19 (1957); Burstein, A Theory of Full Line Forcing, 55 Nw. U.L. REv. 62 (1960); Markovits, Tie-ins, Reciprocity, and the Leverage Theory, Part I, 76 YALE L.J. 1397 (1967); Markovits, Tie-ins, Reciprocity, and the Leverage Theory, Part II, 80 YALE L.J. 195 (1970); Turner, The Validity of Tying Arrangements Under the Antitrust Laws, 72 HARv. L. Rev. 50 (1958).

Tie-ins may violate both sections one and two of the Sherman Act and section three of the Clayton Act. See Northern Pac. Ry. v. United States, 356 U.S. 1 (1958); Times-Picayune Publishing Co. v. United States, 345 U.S. 594, 595-609 (1953). Nevertheless, Washington Gas Light Co. did not allege that VEPCO's scheme constituted a tying arrangement im violation of section three of the Clayton Act; one can only speculate as to why this omission was made. In the interest of analysis this paper will discuss the possibility that VEPCO's scheine was an illegal tying arrangement under section three.

12. See United States v. Loew's, Inc., 371 U.S. 38 (1962). The Court has never fully explained why it adopted this expanded view of tie-ins, and some explanation is necessary. Consider the case where $D$ has market power in the $X$ inarket and none in the $Y$ market. Assume that $D$ offers $X$ at a very low price when bought with $Y$ and at some higher price when bought alone, but without economies of joint production or marketing to explain the practice. If the "alone" price is the price that would have prevailed in a competitive market for $\mathrm{X}$, two possibilities concerning the "together" price arise. First, the low "together" price for $X$ might be balanced by a supra-competitive "together" price for $Y$, so that the price for $X$ plus $Y$ equals the combined prices a consumer would pay buying $X$ and $Y$ separately. In that case, no one is adversely affected. Second, the low price for $X$ and $Y$ when bought together might be lower than the combined prices a consumer would have paid buying $X$ and $Y$ separately. In that case, $D$ is operating below his marginal cost level and is sustaining an economic loss. This practice might be a temporary advertising ploy, or it might be predatory pricing: taking a loss in the $\mathrm{Y}$ market in order to drive $\mathrm{Y}$ coinpetitors out of the inarket. If it is a temporary advertising ploy, it is a matter of little antitrust concern, and predatory pricing is seen by most economists as something of a myth, a theoretical possibility that seems never to be einployed in practice. See Bork, Resolved: Present Antitrust Restraints on Pricing Should Be Relaxed (First Affirmative), 41 A.B.A. ANTITRUST L.J. 8, 15 (1971).

If, however, the "alone" price for $X$ is much greater than the price that would have prevailed in a competitive market for $\mathrm{X}$, the situation is significantly different. In that case consumers who want $X$ are not indifferent between buying $X$ alone and buying $X$ plus $Y$, for the price on $X$ alone makes such a purchase unreasonable to the extent that the difference in the $X$ prices exceeds the consumer's dissatisfaction with this manufacturer's $Y$ product. If, for example, the price charged by IBM for a computer when bought alone is $\$ 50$ million, whereas the price when bought with a full supply of punchcards is $\$ 500,000$, with the price of punchcards being only slightly higher than the competitive market price, nobody will buy the computer without the cards. Assuming that the courts are interested in protecting the competitors in the punchcard market, this pricing practice would have to be prohibited.

Since only under certain conditions will competitors be harmed when $D$ charges different prices for $X$ when bought alone and when bought with $Y$, it would seem that the courts should not treat all such differential pricing arrangements as illegal tie-ins. The broad rule may reflect faulty analysis, but any other rule may be impractical. Specifically, the courts may consider it impossible, or at least too time-consuming and 
Thus defined, the term seems quite clearly to require two products: $\mathrm{X}$ and $\mathrm{Y}$. In 1953 the Supreme Court decided Times-Picayune Publishing Co. v. United States ${ }^{13}$ on precisely this point, giving birth to the "single-product" defense. The defendant publishing company had been selling advertising space in either its morning or afternoon newspaper only on the condition that the advertiser purchase identical space in both. The plaintiff, a competing afternoon newspaper publislier, alleged that this practice constituted a tying agreement violating section one of the Sherman Act. The Court reasoned that underlying the decisions finding tying arrangements illegal was a forced purchase of a distinct second commodity with the purchase of a dominant tying product, resulting in deereased competition in the tied market. In contrast, in Times-Picayune "two newspapers under single ownership at the same place, time, and terms sold imdistinguishable products to advertisers." ${ }^{14}$ There was therefore no dominant tying product; no leverage in one market excludes sellers in a second market because for antitrust purposes "the products are identical and the market the same."15 Thus, even thougl the defendant forced advertisers to purcliase a greater quantity of advertising than they would have purchased absent the scheme, the lack of separately identifiable products was a sufficient defense to the tie-in charge. ${ }^{16}$

speculative, to determine whether the "alone" price for $\mathrm{X}$ is the price that would have prevailed in a competitive market for $X$.

13. 345 U.S. 594 (1953).

14. Id. at 614 .

15. Id.

16. Under the facts of the Times-Picayune case as interpreted by the Court, any advertiser who wanted to reach consuners numbering greater than the circulation of the Times-Picayune's competitor but less than the circulation of all three newspapers would have to forego placing any advertising in the competitor newspaper. One can therefore argue that practically speaking, the arrangement, if not a tie-in, was forced exclusive dealing-that is, an arrangement whereby the buyer promises a seller of $X$ not to buy $X$ froin anyone except that seller.

In a sense this charge can be made against anyone who charges a supra-competitive price for his product; since the additional money extracted from the buyer cannot be spent elsewhere by the buyer, the buyer "proimises" not to deal with some other firm. Even though this logic could produce absurd results, courts should frown upon arrangements like the Times-Picayune one where their effects upon competitors are similar to those of traditional exclusive-dealing contracts.

Although the Court did not find exclusive dealing in Times-Picayune, it seems to have recognized and apphed this type of reasoning five years before. In United States v. Griffith, 334 U.S. 100 (1948), the Court found a violation of sections one and two of the Sherman Act when the owner of a cham of theatres bargained for all of his theatres when he sought filins from film distributors. The evil discerned by the Court was that the defendant had theatres in some towns where his were the only thcatres, and the Court thought this localized market power could be used to pressure film distributors into giving the defendant the rights to valuable films in towns where the defendant's theatres had competition. 
There is a second use for the single-product defense. Under the definition of tie-ins I have given, virtually any sale of any consumer product could constitute a tie-in, since nearly every product is a combination of separately produced parts, none of which the end-product seller will sell alone. Since one of the purposes of the antitrust laws is to promote economic efficiency, it would be undesirable to require every producer of every end-product to offer for separate sale each component part of his principal product, if such a requirement would lead to inefficiency in production or distribution.

In response to this problem the Court in United States $v$. Jerrold Electronics Corp. affirmed per curiam a district court opinion that stated, "[A]s a general rule, a manufacturer cannot be forced to deal in the minimum product that could be sold or is usually sold." lower court held that Jerrold's policy of selling several components only in full systems "was a necessary adjunct to its policy of coinpulsory service."18 A full system could thus reasonably be called a single product as long as it was necessary for Jerrold to require a service contract. However, once the need for compulsory service diminished, the economic reasons for selling only complete systems would be eliminated, and a full system would no longer be an appropriate sales unit. ${ }^{19}$

Following Jerrold, therefore, it was clear that two products would be viewed as one for antitrust purposes if econoinic considerations justified unit sales. Jerrold also demonstrated that there is nothing sacred about two items being called one product or two; the same two items can be one legal product at one time and two at another. Indeed, broadly read, Jerrold completely overturns the per se rule against tie-ins. The only difference between what the Jerrold court did and the "rule of reason" inquiry into economic effects is that the court in Jerrold asked whether there was any reason to treat two products as one, rather than asking the direct question whether there was any reason to hold the tie-in illegal. By these conceptual gymnastics the court in effect joined the critics of the per se rule against tie-ins.

The most recent case involving the single-product defense which the Supreine Court has decided is Fortner Enterprises, Inc. v. United States Steel Corp. ${ }^{20}$ There the plaintiff alleged that U.S. Steel had einployed tying agreements in violation of sections one and two of the Sherinan Act by extending credit only on the condition that the plaintiff agree to buy a nuniber of U.S. Steel's prefabricated liouses. U.S. Steel contended that credit plus houses constituted a single product, but the Court rejected the defense and reversed the summary judgment for
17. 187 F. Supp. at 559.
18. Id. at 560 .
19. Id.
20. 394 U.S. 495 (1969). 
U.S. Steel. The Court did recognize, however, that every tie-in case starts out with the problein of determining whether there are in fact two separate products, and that credit may "constitute such an inseparable part of the purchase price for the item that the entire transaction could be considered to involve only a single product."21 Thus, Fortner, although perhaps wrongly decided, ${ }^{22}$ reaffirmed the principle laid down in Jerrold a decade before: whether two goods or services will be treated as one will depend upon the economic justifications offered for unit sales.

This was the state of the single-product defense when Washington Gas Light Co. v. Virginia Electric \& Power Co. arose. Both uses of the defense were possible in the case, though the circuit court seems to have seen only one. As we shall see, even the one was enough to wreak havoc.

II

The Stngle-Product Defense IN THe Electrical INDUSTRY AND OTHER REGULATED INDUSTRIES

\section{A. The VEPCO Court's Analysis}

The district court opinion in VEPCO does not discuss the singleproduct defense, presuniably because the defendant failed to assert it at that level. The issue was raised on appeal, however, and the Court of Appeals for the Fourth Circuit, rejecting the notion that electricity could be tied to URD, held that "VEPCO sold only one productelectricity."23 The opinion seens to offer two reasons for this conclusion. First, "The delivery of [electricity] has always been an ancillary and necessary part of the business of producing and selling electrical power."24 Second, "There was no separate market for the installation of underground wiring . . . . That there are not dual markets strongly suggests there are not separate products." ${ }^{25}$ It is unclear whether the "ancillary and necessary" argument is offered simply as proof of the asserted existence of only one nnarket or as a distinct reason for finding merely one product. Whichever the court intended, its reasoning misses the mark, and its conclusion is unjustified.

First, if by finding the delivery of electricity to be an ancillary part of the business of producing and selling electricity the court meant that the company which generated the electric power-VEPCO-had always sold the service of dehivery along with the power itself, its ob-

21. Id. at 507.

22. See Note, Credit as a Tying Product, 69 CouvM. L. Rev. 1435 (1969). See generally Bowman, supra note 11; Markovits, supra note 11.

23. 438 F.2d at 253 .

24. Id.

25. Id. 
servation has little bearing on the existence of a separate market for URD. The court failed to distinguish between the service of delivery and the provision of a system for delivery. Even if it were true that a market for undelivered electricity was unlikely, there may still be a separate market for the production and sale of the delivery systemURD or overhead lines, for example.

If the court meant to subsune the provision of a delivery system in the term "delivery of electricity," its observation on the ancillary nature of delivery is still unilluminating. Since VEPCO had always supplied essentially the entire geographic narket for both electricity and delivery systems, the court could not have known without careful economic analysis whether the dual sales by the one firm resulted from an unnecessary and undesirable extension of a legal monopoly or from characteristics of the products which negated the possibility of two markets. $^{26}$ Moreover, it can be said of inany products, for which, like electricity, there is an extensive geographic market and centralized supply, that the provision of means of delivery of the product to various purchasing sites is ancillary to sales of the product. Consider, for example, an automobile inanufacturer in Detroit which delivers its product across the country by railroad. In the face of intense competition among railroad, truck, and barge systems, courts would be unlikely to conclude that no separate inarket exists for systems of shipping consumer goods. The "shipping" of electricity and the shipping of consumer goods can be distinguished, but not on the ground that the systein for delivering the product is ancillary in one case to sales of products but is not in the other. ${ }^{27}$

26. The importance of this distinction is discussed at length in the text accompanying note 41 infra.

27. Strangely, the VEPCO court noticed that the delivery of electricity is somewhat comparable to the delivery of other products but failed to draw the proper conclusions. Its recognition of the analogy is apparent from its verbatim imcorporation iu its opinion of Judge Elliot's observations in a similar case, Gas Light Co. v. Georgia Power Co., 313 F. Supp. 860, 869 (M.D. Ga. 1970), aff'd per curiam, 440 F.2d 1135 (5th Cir. 1971):

To my mind, [URD] is merely a method by which a product-electricity-is

delivered to the cousumer. It might be compared to a department store's

delivery of merchandise bought by a customer living fifteen miles out in the country-if that customer bought a single necktie it is doubtful the store would treat the delivery the same way it would if the custonner bought a wardrobe. [URD] is ancillary to both the seller and buyer of the product, in much the same way as a free meal given to an airline passenger is ancillary to the sale of an airline ticket.

Both of Judge Elliot's examples militate against a finding of one product in VEPCO's scheme. First, that a department store will deliver a wardrobe but not a single necktie indicates that there is no economic tie between delivery and the consumer product. Rather, whether or not delivery will be giveu "for free" depends solely upon the size of the purchase, presumably in order to encourage large purcliases. Indeed, one miglit well argue that small-quantity purchasers are partially sub- 
The court also found that the delivery of electricity had always been a "necessary" part of the business of producing and selling electricity. ${ }^{28}$ If by necessary the court ineant electricity is worthless unless used in conjunction with a delivery system, this observation, too, was irrelevant to the question of whether two markets existed. The foregoing automobile example agam demonstrates the point; but consider, in addition, electric lightbulbs. Electricity and its delivery are necessary for the operation of hightbulbs. But no court would accept the contention that lightbulbs and electricity or lightbulbs and URD therefore constitute one product, or that there is no separate market for hightbulbs. In fact, the same type of "necessary" reasoning could be applied to some classic tying cases-for example, computers and computer cards $^{29}$ or salt machines and raw salt. ${ }^{30}$

On the other hand, "ancillary and necessary" could signify simply that economic justifications for the historical pattern of eleetricity and an electricity delivery system always being sold together constitute a separate reason for sustaining the single-product defense; that is, it is not economically feasible to produce and sell thein separately. ${ }^{31}$ But two factors suggest that this was not the courts intended meaning for the phrase. First, the court did not adduce any evidence to support the supposed economic justifications. Indeed, at least a few builders installed URD without VEPCO's assistance, ${ }^{32}$ and companies other than VEPCO often performed the trenching and back-filling which were integral parts of URD installation; ${ }^{33}$ this suggests there was little or nothing involved im installing URD which bore a special relationship to the supplying of electricity by the owner of the power plant, VEPCO.

sidizing "free" delivery for large-quantity purchasers, since the cost of delivery must be accounted for in the prices of the various products.

Second, the airline ticket and "free" meal are as questionable under the antitrust laws as URD plus electricity. Unless the airlines can demonstrate that definite economies are achieved by providing all passengers with a meal rather than allowing passengers to choose whether or not to eat and to pay or not pay accordingly, that scheme, too, should constitute an illegal tying arrangement.

28. 438 F.2d at 253.

29. See International Business Machs. Corp. v. United States, 298 U.S. 131 (1936).

30. See International SaIt Co. v. United States, 332 U.S. 392 (1947).

31. Professor Markovits has denronstrated that economic justifications for tie-ins may exist even though the tie-ins do not reduce the actual costs of production. For example, if tie-ins are used to provide the seller with a counting device-a device which tells hin how much each purchaser is using the tying product so that price discrimination can be employed-there may be a social cost to forcing the seller to enploy soine more elaborate and less efficient discriminating tool. See Markovits, supra note 11.

32. 309 F. Supp. at 1120.

33. The VEPCO scheme required builders who refused to go all-electric to provide their own trenching and back-filling. See id. at 1121. 
If this is true, it seems unlikely that any actual costs were cut by VEPCO's combined sales of URD and electricity. Furthermore, as Professor Turner has observed, inost cost savings occur in the assembly process at the plant. ${ }^{34}$ If two items-URD and electricity, for example -are assembled at the site of installation or purchase, purchase of the two as a unit is not likely to yield significant savings.

Second, if the court meant by "ancillary and necessary" that there were economic justifications for the historical pattern of electricity and a delivery systein being sold together, the finding was nothing less than a conclusion that the delivery systern and electricity should be treated as a single product under the antitrust laws. Any further inquiry into the existence of separate markets would have been unnecessary; once a court has found that economic considerations compel the offering of two items for sale as a package, the essential test for calling the items a single product has been met. ${ }^{35}$

Failure to undertake a careful economic analysis also led to the court's conclusory finding that there was "no separate market for the installation of underground wiring as there was a separate market for credit in Fortner."36 By attempting to distinguish the credit market, the court seems to have intended to suggest that separate markets for two items exist only if each of the two examined items can be purchased from several sources. Apparently, the factor which misled the court was VEPCO's virtual monopoly over the imstallation of URD. Because VEPCO always supplied electricity, and because when URD was requested, VEPCO almost always performed the installation, the court concluded that the sale of the two items by the same company involved certain economies and therefore indicated the existence of a single market.

But a monopoly over two related products does not necessarily indicate that there is a single market. Indeed, there are several explanations for a monopoly over both products that can be posited:

34. The typical way in which costs are saved by the amalgamation of components previously sold separately is by the transfer of assembly from buyer's site to seller's factory. For example, the greatest strides iu reducing construction costs have come through prefabrication; not only have labor costs been reduced, but factory fabrication has enabled and stimulated the use of new materials more amenable to mass-production technique. Since [the hypothetical seller] installs on the site just like anyone else, it is difficult to say that he is selling a "new" prodnct. It is likely that his package sale has restrictive rather than beneficent motivations.

Turner, supra note 11, at 71-72.

35. See Bowman, supra note 11, at 29; cf. United States v. Jerrold Electronics Corp., 187 F. Supp. 545, 559 (E.D. Pa. 1960), aff'd per curiam, 365 U.S. 567 (1961); Turner, supra note 11 , at $62-64$.

36. $438 \mathrm{~F} .2 \mathrm{~d}$ at 253. The court's reference is to Fortner Enterprises, Inc. v. United States Steel Corp., 394 U.S. 495 (1969). 
One, as the court suggested, is that there is some connection between the products that provides a sound reason for viewing them as one product for antitrust purposes. But another explanation is that although consumers would, if given the chance, often purchase one of the two related iteins from a separate producer, one producer has protected monopolies over both items. Another possible reason is that although consumers would purchase the two items separately if given the chance, one producer has always had a monopoly over one which he has used to subsidize low profits ${ }^{37}$ on the sales of the other, thus preventing other producers from entering the market for the low profit product. In short, it is senseless to say that because product $Y$ is always sold with product $X$, defendant could not have used a monopoly over $\mathrm{X}$ to force consumers to purchase product $\mathrm{Y}$.

The problem raised by VEPCO's treatment of URD can thus be seen to be older than the advent of URD. VEPCO had traditionally provided overhead lines "for free" before and after URD became feasible and popular. ${ }^{38}$ Clearly, however, VEPCO did not really provide overhead lines for free. Rather, it collected the amount it had expended in installation costs with higher electricity rates. It may well be, therefore, that even the market for overhead lines was potentially competitive, and that VEPCO had even before URD kept out potential competitors for electricity delivery systems by subsidizing its losses with its electricity monopoly. ${ }^{30}$

To sum up this point, the court erred in its analysis by concluding that there was no separate market for URD from the simple fact that delivery systems had generally been provided by VEPCO.40 In cases where a single producer has historically been the sole supplier of the two items being examined, two questions must be asked: (1) Would consumers want to purchase the items from different producers if given the opportunity? (2) Can producers sell the items separately without incurring prohibitive costs? The first question is partially subsumed by the second, because producers' ability to sell the items

37. The use of the term "profits" here corresponds to the layman's use rather than the economist's; i.e., by profits I mean any amount in excess of costs of production where such costs do not include opportunity cost.

38. $309 \mathrm{~F}$. Supp. at 1120-21.

39. If this was the case, VEPCO could be attacked for monopolizing in violation of section two of the Sherman Act. See United States v. Griffith, 334 U.S. 100 (1948).

40. Unfortunately, the appeals court's mishandling of the single-product defense was not himited to analytical errors. The fact is that VEPCO did not sell electricity and a delivery system as a package once URD became popular. VEPCO's scheines offered builders several choices: overhead lines supplied by VEPCO for free; URD provided by VEPCO for free; partial URD provided by VEPCO for free; URD provided by VEPCO for a price; and URD provided by the builder himself. $309 \mathrm{~F}$. Supp. at 1120-21. 
separately without incurring prohibitive costs will depend upon the demand for the separate products. If only a handful of purchasers would take advantage of separate sales, sufficient economies of scale in storage and marketing-to name but two possibilities-would not likely be realized. But the importance of the two questions lies in the words "would" and "can," for they emphasize that the courts must examine likelihoods and possibilities, not just historical patterns. Just as in defining relevant geographic markets we speak of the area in which producers could be located and still compete for particular consummers' dollars, ${ }^{41}$ here we want to know what producers could economically produce and market.

\section{B. Implications for Regulation}

There is an important lesson for regulatory agencies in the court's failure to recognize the breadth of the tie-in problem in regulated industries. Regulated firms may currently perform several functions, but it may not be necessary for them to perform all of them. To the extent that they perform functions which could be performed by entities in a competitive market, there is excessive regulation of our otherwise freemarket economy. Especially in view of soine recent attacks on all public regulation of private enterprise, ${ }^{42}$ it behooves regulatory agencies to pare the scope of regulated firms' operations to the bare economic necessities.

Alternatively, it may be that the regulatory agency cannot or does not wish to pare the scope of the firm's operations. In that case the agency should at least ensure that all of the firm's operations are individually price-regulated, for several problems might otherwise arise.

First, the price for the unregulated function may be too high. Even if the firm has a legitimate monopoly over that function because it must be performed in conjunction with the regulated function, the company may thereby earn greater profits than it should. Since profits are generally regulated, however, such "hidden" profits would be difficult to obtain. More realistically, the company's high price for the unregulated function may reflect inefficient operations. Momitoring expenses is not an unusual role for regulatory agencies, since they regularly examine alleged operating costs and try to hold them to reasonable levels. If the agency carefully watches the expenditures for each function, it may thus be able to ensure greater efficiency.

41. See, e.g., United States v. Philadelphia Nat'1 Bank, 374 U.S. 321, 357-62 (1963); Brown Shoe Co. v. United States, 370 U.S. 294, 328, 336-38 (1962); Tampa Electric Co. v. Nashville Coal Co., 365 U.S. 320, 330-33 (1961).

42. See, e.g., L. KohlmeIer, Thr Regulators (1969); Posner, Natural Monopoly and Its Regulation, 21 STAN. L. REV. 548 (1969). 
Second, the price for the unregulated product may be too low. If the regulated firm has a legitimate monopoly over the unregulated function, and if it charges a price that is too low, the difference between its price and the marginal-cost pricing level will have to be balanced by excessive prices for the price-regulated service. For example, VEPCO's free installation for overhead lines had to be balanced by higher electricity rates. Thus, persons who used inore electricity paid for portions of low-users' overhead installation costs. For VEPCO's customers the discrimination or redistribution may not have been very significant, since the differences in amount of electricity used by various customers was probably not too great. Under other circuinstances in other regulated industries large variations in the amount of the basic product used might make such a redistribution quite inequitable.

If the regulated firm does not have a legitimate monopoly over the unregulated function-i.e., there are no economic justifications for packaging that function with the price-regulated function-it cannot charge too high a price without inducing competition from other sources. For example, if VEPCO did not have a legitimate monopoly over URD, it could not set a very high price for URD purchased with only minimuin electric service without mducing builders to employ general contractors to install URD. But the regulated firm can still charge too low a price, either intentionally or unintentionally, and thereby prevent coinpetitors from entering the market for the unregulated function. Not only does this foreclose those potential competitors, but it again means that the loss inust be coinpensated for by excessive prices in the price-regulated function. Finally, as with VEPCO's "free" overhead lines, a low price or a price of zero may tend to prevent consumers from rejecting a product or service they do not particularly want, simply because the artificial price discrepancy between that and the more desired product or service is too great to ignore.

Examples of the kind of problein just described abound: "free" installation of equipment in the electrical industry; "free" ineals, "free" headsets, "free" movies, "free" soft-drinks while hquor drinkers pay, and other such "gifts" on the airlines; the link between the provider of telephone service and the manufacturer of telephone equipment; "free" water softening by water suppliers. Surely there are other imstances in which the problein arises, but these few suffice to demonstrate that many regulatory agencies daily iguore, consciously or unconsciously, the type of problem the court inishandled in Washington Gas Light Co. v. Virginia Electric \& Power Co.

\section{Determination of the Tying and Tied Products}

To some extent the whole discussion in the VEPCO decision of 
whether URD is a product separate from electricity was unnecessary. The court could have avoided it by carefully defining the tied and tying products. Since there was an alleged exercise of market power by VEPCO, the court should have sought to determine exactly where the power lay and how it was exercised (although the court's failure to do so can perhaps be attributed to the plaintiff).

Assume, for the moinent, that the tymg product was, as plaintiff alleged, URD - that is, that the defendant employed a scheine which made it unrealistic to suppose that builders could obtain URD without purchasing something else from VEPCO..$^{43}$ What was it that builders were forced to buy in addition to URD? In many cases, it was not any particular anount of electricity or electricity at all-the link with which the court preoccupied itself. Builders often are neither the owners of the property nor the potential users of the completed buildings. Rather, builders frequently build on contract for developers, who sell the finished buildings to home-buyers or rent the finished buildings to apartment dwellers and office users. Under such circumstances, if the builder has the authority to decide to install URD and does so, he is forced by the VEPCO scheme to buy the additional non-URD-related materials and services needed to make the building all-electric: more internal wiring, more electricians' time, electric water heaters, and electric space heaters, to name but a few. Where he might otherwise have installed gas lines, gas water heaters, and plumbing, he uses electrical equipment. The court could no more call URD the saine product as this equipment than it could call URD the same product as a refrigerator or clothes dryer. This is not to say that the builder does not pass on the cost of electrical equipment to the developer and other owners with whoin he has contracted, but the passing-on defense is an entirely separate issue. ${ }^{44}$

Section three of the Clayton Act proscribes only tying agreements which prevent the purchaser from dealing in the products of "a competitor or competitors of the lessor or seller." ${ }^{45}$ If VEPCO did not sell the equipinent and services builders had to buy to go all-electric, builders

43. Classically, tie-ins are agreements which result when the seller of product $X$ refuses to sell that product unless the buyer agrees to purchase product $Y$ also. The situation alleged against VEPCO is a variation on that theme. See note 12, supra.

44. The passing-on defense is a defense asserted in private antitrust actions for treble damages, whereby the defendant asserts that whatever damage the plaintiff may have suffered due to defendant's actions was recovered by the plaintiff by raising the price it charged its customers. See Hanover Shoe, Inc. v. United Shoe Mach. Corp., 392 U.S. 481 (1968); McGuire, The Passing-On Defense and the Right of Remote Purchasers to Recover Treble Damages Under Hanover Shoe, 33 U. PITT. L. REv. 177 (1971); Pollock, Automatic Treble Damages and the Passing-On Defense: The Hanover Shoe Decision, 13 ANTTrRusr BulL. 1183 (1968).

45. 15 U.S.C. \& 14 (1970). 
forced by VEPCO's scheme to purchase such items rather than gas-related items were not in that sense prevented from dealing with VEPCO's competitors. Tying arrangements, however, are also subject to attack under the Sherman Act, ${ }^{46}$ which does not contain the limiting language of section three of the Clayton Act. ${ }^{47}$ Thus, the court could have found the tied product to be the equipment and services needed for all-electric service.

Such a finding would have expanded existing tie-in law by protecting firms with which the tying seller did not compete. There could be no pretense of declaring the arrangement illegal on the ground that VEPCO was trying to use a monopoly over $X$ to produce a monopoly over $\mathrm{Y}$, because I have assumed that VEPCO produced no $\mathrm{Y}$. Thus, the court would have had to rely on the argument that tie-ins should be proscribed when they hurt competitors, even if there is no threat of a monopoly. The Supreme Court has on several occasions suggested that this is the primary reason for the interdiction of tieins, ${ }^{48}$ but several commentators have taken the Court to task for protecting competitors rather than competition. ${ }^{40}$ Nevertheless, since the Court has sanctioned an approach to tie-ims which protects competitors, it seems logical to extend that protection to competitors of the firms directly benefiting froin a tie-in such as VEPCO's.

The impact of the exercise of VEPCO's market power over URD -still assuming, arguendo, that there was an exercise of such powerwould be even more substantial in instances where the builder also owns and uses the buildings. In those cases he would have to buy not only the internal wiring and other materials needed to install an allelectric system but also electrical apphiances-for example, electric ranges and dryers-rather than gas apphances.

In addition, the builder-owner-user would be forced by the VEPCO scheme to buy the additional electricity he would use by going all electric in order to obtain URD. This is one step removed from the classical tying cases, because in those the purchaser is made to

46. See, e.g., Fortner Enterprises, Inc. v. United States Steel Corp., 394 U.S. 495 (1969); Northern Pac. Ry. v. United States, 356 U.S. 1 (1958); Times-Picayuno Publishing Co. v. United States, 345 U.S. 594 (1953).

47. See 15 U.S.C. $\S \S 1,2$ (1970).

48. See Fortner Enterprises, Inc. v. United States Steel Corp., 394 U.S. 495, 498-99, 504, 508-09 (1969); United States v. Loew's Inc., 371 U.S. 38, 45, 49 (1962); Northern Pac. Ry. v. United States, 356 U.S. 1, 6 (1958); Times-Picayune Publishing Co. v. United States, 345 U.S. 594, 605-06 (1952). See generally Kauper, The "Warren Court" and the Antitrust Laws: Of Economics, Populism and Cynicism, 67 Mict. L. Rev. 325, 332 (1968); Note, The Logic of Foreclosure: Tie-In Doctrine after Fortner v. U.S. Steel, 79 YALE L.J. 86, 92-101 (1969).

49. See, e.g., Bork, The Rule of Reason and the Per Se Concept: Price Fixing and Market Division, 74 YaLE L.J. 775 (1965). 
promise to buy $\mathrm{Y}$ if he is to be permitted to buy $\mathrm{X} .{ }^{50}$ Here, the buyer does not promise to buy additional electricity, but the practicalities of the situation ensure that he will do so. For example, once electrical heating systems are installed, it becomes highly improbable that the owner will incur the great expense involved in switching to gas. ${ }^{51}$

In spite of the additional analytical step, no additional legal problems accrue; section three of the Clayton Act requires only a "condition, agreeinent, or understanding"52 that the purchaser will not deal in the goods of the seller's competitors. Indeed, even classic tie-ins required some substantial reliance on that phrasing in order to be held to fall within the purview of section three. In United Shoe Machinery Corp. v. United States ${ }^{53}$ the Supreme Court recognized that tie-in contracts "do not contaim specific agreements not to use the inachinery of a coinpetitor of the lessor," $"$ 4 but it nevertheless held that "the practical effect of these drastic provisions is to prevent such use. We can entertam no doubt that such provisions as were enjoined are embraced in the broad terms of the Clayton Act, which cover all conditions, agreements, or understandings of this nature."

Furthermore, since the Sherinan Act's language is broad enough to allow a similar interpretation, ${ }^{56}$ the court could easily have found the additional electricity to be a tied product in violation of the Sherman Act. The only reinaining obstacle to such a finding under either act 1might be the court's refusal to treat additional electricity as a product differing froin minimal electricity for purposes of the single-product defense.

In fact, the court's approach on this point exposes the basic problem with its analysis; the second purpose of the single-product defense was in issue without the court ever seening to realize it. The court stated that it could see only one product: electricity. ${ }^{57}$ To reach that conclusion it had to take two steps. First, as I have already discussed, it had to find that URD was, in its words, a delivery system so "ancillary and necessary" to the sale of minimal electricity-the amount needed for hights, television sets and so forth-that URD plus minimal electricity comprised but one product. Second, it had to find that although

50. See, e.g., International Salt Co. v. United States, 332 U.S. 392 (1947); International Business Machs. Corp. v. United States, 298 U.S. 131 (1936).

51. See 309 F. Supp. at 1126.

52. 15 U.S.C. $\$ 14$ (1970) (emphasis added).

53. 258 U.S. 451 (1922).

54. Id. at 457.

55. Id.

56. See 15 U.S.C. $\$ \S 1,2$ (1970).

57. See 438 F.2d at 253. 
additional electricity-the amount needed for space heating and water heating, for example - had a good substitute readily available which minimal electricity did not, minimal electricity and total-electric electricity were also one product. In short, the court had to find that URD, minimal electricity, and total-electric electricity were all one legal product.

But the court did not even consider the possibility that there was a tying arrangement involving URD plus minimal electricity as the tying product and additional electricity as the tied product. Apparently because minimal electricity and additional electricity are merely different amounts of the same physical product, the court permitted the single-product defense to prevail. Precedent seemed to support this approach. All prior tying agreements declared illegal by the courts had involved distinct physical products-for example, salt machines and salt, ${ }^{58}$ computers and punchcards. ${ }^{50}$ Moreover, one of the country's foremost antitrust commentators had written that one of the essential elements of a tying violation is two "obviously different products." Finally, the Supreme Court in Times-Picayune seeined to suggest that the defendant prevailed because only one physical product-advertising-was involved. ${ }^{61}$

The problem raised by such a simplistic approach can be demonstrated by considering sparkplugs as an example. Probably no one would deny that a new automobile sold with sparkplugs in it comprises a single product under the antitrust laws, because it is nearly impossible to transport a car and prepare it for transfer to the customer without sparkplugs. Yet it is equally clear that there is a separate market for sparkplugs: the replacement market, which in fact accounts for most sparkplug sales. ${ }^{62}$ Thus, sparkplugs are simultaneously one product with new automobiles and a separate product in the replacement market. If General Motors were to sell its cars only on the condition that purchasers promise to buy their replacement sparkplugs froin its subsidiary, the arrangement should be classified as a tying agreement. The same can be said for promises regarding replacement of tires, oil filters, points, condensers, air filters, and that first "free" tank of gasoline.0

58. See International Salt Co. v. United States, 332 U.S. 392 (1947). (1936).

59. See International Business Machs. Corp. v. United States, 298 U.S. 131

60. Turner, supra note 11 , at 62 .

61. See text accompanying note 18 , supra.

62. See Ford Motor Co. v. United States, 405 U.S. 562 (1972).

63. This reasoning could logically be extended to include instances in which General Motors, for example, designs its sparkplug receptacles so that they are able to accommodate only certain patented sparkplugs. If the design is employed solely to 
Similarly, even if minimal electricity and URD are considered one product for tie-in analysis, the additional electricity used in allelectric households probably should not be seen as an additional component of that same legal product. Even if there is some economic justification for unit sales of URD and electricity, it seems unlikely that the amount of electricity used after the URD has been installed plays a significant role in that justification.

The general rule I am proposing here is fairly simple: If an item nuust for some reason be produced and marketed with other items as a unit for sone purposes, but is demanded and can profitably and economically be produced and sold as a separate item for other purposes, that item should analytically and legally be described as two products for tie-in purposes. In its unit role it should be considered just one of the several constituent parts of the unit. But with reference to future sales of the itent apart from the unit, it should be considered a distinct product. In fact, the only difference between these cases and the classic tying cases involving products which are used in variable proportions with respect to each other-conputers and punchcards for instance-is that here some minimal quantity of the tied product is a part of the tying product, and the additional quantities comprise the tied product. In the IBM case, on the other hand, no coniputer cards had to accompany the machine for the machine to be sold and transferred, so it was easy to view the 1nachine and the cards as distinct products.

From this point it would be just a sunall step to conclude that even by ignoring URD-which the VEPCO court essentially did by calling URD and electricity one product-a court could find minimal electricity and the additional electricity needed for all-electric operation to be separate products. The peculiar feature of the case which would have allowed the court to reject the single-product defense even though only one physical product was involved was the kinked deniand curve faced by VEPCO. An exaggerated picture of the demand curve for electricity would look like this:

prevent use of other brands of sparkplugs, rather than for some aesthetic, functional, quality-control, or cost reason, this amounts to a forced purchase of Champion sparkplugs for anyone who wishes to purchase a General Motors automobile. But generally this forced purchase will be economically impossible to effectuate where legitimate design motive is lacking. Not only will engineering costs often be prohibitive, but competitors have a knack for discovering ways to circumvent barriers requiring only engimeering ingenuity. Finally, proving a total lack of sound design motive will be very difficult and will involve considerable speculation. The improbability that only a tie-in was intended, the improbability of proving such a narrow intention, and the potential drain on scarce judicial resources seem to preclude suits based on such a theory. 


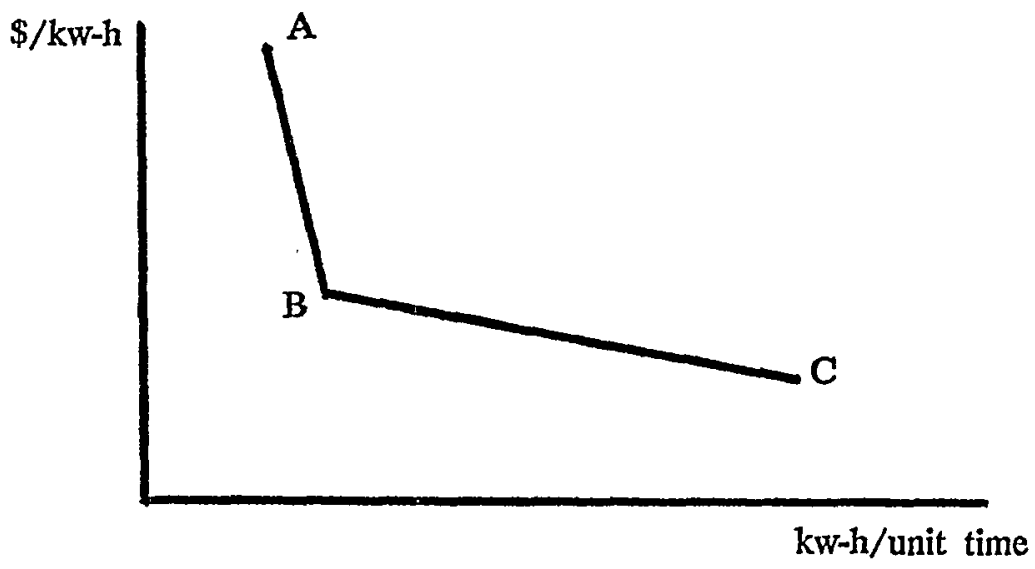

The left-hand portion of the curve (AB) indicates that the demand for a certain limited quantity of electricity is highly melastic: VEPCO has a wide range over which it can vary its price per unit of electricity while still selling approximately the saine anount of electricity. This is true because almost every American is highly dependent upon electricity for lighting and other "essential" uses and because VEPCO has a legal inonopoly over electricity. The right-hand portion of the curve (BC) indicates that the demand for electricity at some point becomes highly elastic: VEPCO cannot raise its rates very far without losing some substantial portion of its business to the Washington Gas Light Company.

This kinked demand curve reflects the fact that VEPCO could use its power over minimal electricity to force consumers to buy additional electricity. More precisely, VEPCO could exploit its power over minimal electricity either by cliarging high prices for it or by charging lower prices and requiring consumers to buy something they would not otherwise have bought-more electricity for additional uses. Since its prices are regulated, however, VEPCO really had only the latter possibility.

Where such a situation exists, one of the principal problems seen by the courts in tying agreements arises: Competitors are foreclosed from coinpeting with the defendant in their area of direct competition by the defendant's exercise of its power in an area in which it has no competition. This is not the place to enter the debate as to whether the antitrust laws and tie-in law in particular should protect competitors or competition, or whether protecting competitors does protect competition; ${ }^{64}$ but since the courts have decided to protect competitors

64. See generally Brown Shoe Co. v. United States, 370 U.S. 294, 344 (1962); Klor's, Inc. v. Broadway-Hale Stores, Inc., 359 U.S. 207 (1959); United States v. Aluminum Co. of America, 148 F.2d 416, 427 (2d Cir. 1945); Bork \& Bowman, 
from tying devices, ${ }^{65}$ consistency requires that the kinked-demand-curve cases involving a single physical product be treated accordingly.

The precise cases involving kinked demand curves with which the courts should be careful are those in which one physical product has several uses but there are competitive products for only some of those uses. If power over the product for those uses for which there is no substitute product is used to force consumers to purchase additional quantities of the product, thereby preempting other products, the singleproduct defense can be rejected. These cases are likely to arise not only in regulated industries, but also in the patent area. For example, transistors are indispensable for computers but optional for radios and stereos. If a firm with a patent on transistors refuses to sell transistors to a firm which produces coinputers, radios, and stereos unless that firm agrees to use transistors in all of its production lines, the patentee will be exploiting a kinked-demand-curve situation.

Using the foregoing analysis, the VEPCO situation is easily distinguished from Times-Picayune Publishing Co. v. United States, the only Supreme Court case bearing even a vague resemblance. There the Court denied the existence of any functional distinction between inorning newspaper advertising and evening newspaper advertising. Although it recognized that readers consciously distingnished between the nnorning and evening newspapers owned by defendant, the Court observed that this does not necessarily imply that the advertisers bought separate and distinct products. To reach such a conclusion, the Court found, "would involve speculation that advertisers bought space inotivated by considerations other than customer coverage; that their media selections, in effect, rested on generic qualities differentiating morning from evening readers in New Orleans. ... [N]othing in the record suggests that advertisers viewed the city's newspaper readers, morning or evening, as other than fungible customer potential." ${ }^{\text {"B6 }}$ While it can be argued that the Court did not correctly characterize the facts, it is nonetheless true the Court found no distinction between niorning and afternoon readership for advertising purposes. When an advertiser chose between the two or purchased both, he was for his purposes dealing with various quantities of one iten. If he could not obtain morning advertising space, he would happily settle for afternoon space, since his only interest was in the number of readers reached.

Minimal electricity and all-electric electricity, on the other hand, are not fungible. Homeowners would be unwilling to use electricity

The Crisis in Antitrust, 65 CoLUM. L. Rev. 363, $369-70$ (1965); Blake \& Jones, Toward a Three-Dimensional Antitrust Policy, 65 Colum. L. Rev. 422, 439 (1965).

65. See generally Bowman, supra note 11; Markovits, supra note 11; Turner, supra note 11.

66. 345 U.S. at 613. 
only for space heating and water heating, for example, and not have it available for lights and refrigerators. The functional distinction is so great as to make the difference "generic," in the Court's language. Whereas fungibility was shown in Times-Picayune because defendant's morning newspaper competed with its own afternoon paper as well as with the rival afternoon newspaper, neither all-electric electricity nor gas competes with minimal electricity, even though they compete with each other.

\section{Tie-ins and Exclusive Dealing}

Extending existing tie-in law to cover some situations involving only one physical product will further blur a fuzzy line which has bothered antitrust students for years: the line between tie-ins and exclusive-dealing contracts. Classically, tie-ins have involved two distinct physical products; and classically, exclusive-dealing contracts have required buyers to purchase all of their requirements for a single physical product from one seller. ${ }^{67}$ Both have been attacked by the courts on the ground that they harm competitors and competition. ${ }^{68}$

Nevertheless, the Supreme Court has created different tests to determine the legality of each type of arrangement because of its notion that tying agreements "serve liardly any purpose beyond the suppression of competition, [whereas exclusive dealing contracts] may well be of economic advantage to buyers as well as to sellers, and thus indirectly of advantage to the consuming public."'69 Thus, the Court-created test for illegality of a tie-in states: "Tying agreements . . . are unreasonable in and of themselves whenever a party has sufficient economic power with respect to the tying product to appreciably restrain free competition in the market for the tied product and a 'not insubstantial amount of interstate commerce is affected." "70 Furthermore, "sufficient economic power" does not require proof that there is market power or dominance over the tying product; it is enough that the product is viewed as unique by some buyers. ${ }^{71}$

The test for illegality of exclusive-dealing contracts is quite different. The competition foreclosed inust constitute a substantial share of

67. See generally Bok, The Tampa Electric Case, 1961 SUP. CT. REv. 267; Lockhart \& Sacks, The Relevance of Economic Factors in Determining Whether Exclusive Arrangements Violate Section 3 of the Clayton Act, 65 HARv. L. Rev. 913 (1952).

68. See, e.g., cases cited note 48 supra (tie-ins); Tampa Elec. Co. v. Nashville Coal Co., 365 U.S. 320, 327-28 (1961); Standard Oil Co. v. United States, 337 U.S. 293, 314 (1949) (exclusive dealing).

69. Standard Oil Co. v. United States, 337 U.S. 293, 305-06 (1949).

70. Northern Pac. Ry. v. United States, 356 U.S. 1, 6 (1958).

71. See Fortner Enterprises, Inc. v. United States Steel Corp., 394 U.S. 495, 503 (1969); United States v. Loew's, Inc., 371 U.S. 38, 45 n.4 (1962). 
the relevant market. In other words, the opportunities to enter or remain in the market must be significantly limited. Substantiality in each case is determined by weighing "the probable effect of the contract on the relevant area of effective competition, taking into account the relative strength of the parties, the proportionate volume of cominerce involved in relation to the total volume of commerce in the relevant market area, and the probable immediate and future effects which preemption of that share of the market might have on effective competition therein."72 Essentially, a tie-in will be found illegal per se if the tying product is in some way umique and actually forces some buyers to buy two different products from one seller; but an exclusive dealing contract will not be declared illegal unless such a significant number of competitors will be harmed that coinpetition and consumer welfare are threatened.

The difference between the two tests is rather unclear in a large number of conceivable transactions. Moreover, since Jerrold opened the per se rule against tie-ins to the defense of economic justifications, ${ }^{73}$ the difference between the two tests has been reduced to a hair's breadth. This is as it should be. Rigorous analysis by Professor Bowinan and Markovits has demonstrated beyond doubt that, contrary to the Court's pronouncements, there can be and usually are significant social advantages to the use of tie-ins as well as to the use of exclusivedealing contracts. ${ }^{74}$ My examples of single-product tie-ins should go even further toward eliminating the artificial distinction heretofore drawn by the Court between tie-ins and exclusive-dealing contracts.

In fact, I suggest that if the courts wish to have a per se rule against tie-ins-or something that they call a per se rule-there is no justifiable reason for failing to extend that rule to exclusive-dealing contracts required by sellers. The Supreme Court's basic argument for treating exclusive-dealing contracts gently is that they often benefit the buyers and indirectly the consuming public. If that is so, the exclusive-dealing contracts worthy of protection are those requested or bargamed for by buyers, not those required by sellers.

In any event, the court of appeals in the VEPCO case could have found two products at several levels, thereby enabling it to reject the single-product defense. Nor can the court take solace from the fact that some of the two-product combinations involved products perhaps not produced or marketed by the defendant-for example, the equipment and services needed to make a building all-electric; the plaintiff would still be able to show that it was damaged by a violation of that

72. Tampa Elec. Co. v. Nashville Coal Co., 365 U.S. 320, 328-29 (1961).

73. See text accompanying notes 14-20 supra.

74. See Bowman, supra note 11; Markovits, supra note 11. 
nature, albeit indirectly. In short, neither substantively nor procedurally was the court correct in accepting the single-product defense.

III

The Antitrust Effects of Promotional Practices in the
Electrical Industry: A Suggested Analysis

That VEPCO should not have been permitted to prevail on the single-product defense does not mean the district court should have been affirmed. Washington Gas Light Company still had to prove that VEPCO had in fact exercised its market power over URD by employing a scheme that as a practical matter required builders to go all-electric in order to obtain URD. To analyze that assertion fully it will first be necessary to describe in detail the nature of promotional schemes like VEPCO's.

\section{A. Economies of Scale in the Electrical Industry}

As a general matter, especially in the absence of promotional schemes which alter the situation, electrieity consumption is highly cyclical. Maximum demand occurs during the summer months when air conditioners, which are almost always electrical, are being used. Because the electric company as a regulated body must maintain sufficient equipment to supply the demand during the period of maximum load, it will find itself with substantial excess capacity during the months when air conditioners are not in use. To the extent the company can induce consumers to use more electrical devices during the other three seasons, it will be able to operate at a more nearly uniform load level and lence more efficiently. Electric coinparies, therefore, consider it imperative to induce builders of new apartment complexes and homes to use electric space heating in order to imcrease electrical consumption in the colder months. Indeed, if the company cannot so induce the builders, the problem will be exacerbated by new construction; presumably the new buildings will have electric air conditioners, forcmg the peak load even higher without adding a leveling factor for the other inonths.

Another type of economy of scale is achieved by inducing builders to go all-electric. The electric company must be able to supply each new owner's demand for electricity, but the company does not have to install facilities which could meet the anticipated demand for each household if all electrical appliances in the household were used simultaneously. Rather, the company, similarly to actuarial calculations, uses past empirical observations to estimate the likely maximuin demand for a household containing certain electrical items and plans accordingly. The more electrical items employed, the more their use 
will be spread throughout the day, and the lower will be the percentage capacity required for each maximum possible load. For example, an all-electric home will generally have the water heater operating late at night after the family baths, the electric iron, dishwasher and clotheswasher operating during the morning hours, and the television set and stove operating during the early evening; it will thus require little more electricity at any one time than a home with only minimal electricity, while using much more electricity over the whole day.

This same principle works for whole communities. The larger a community, the more diversified its use of electricity is likely to be; and the more the company can induce businesses and families to go all-electric, the more uniform the load is likely to be throughout the day. Thus, for example, the Kansas Power and Light Company charges lower rates per unit of electricity in larger towns than it does in smaller towns, reflecting its lower costs per unit when more of the maximum capacity is in use at any one time. ${ }^{75}$ The electrical company which induces builders to go all-electric can therefore achieve substantial economies of scale.

\section{B. Devices for Distributing Scale Savings}

The question then becomes one of what the company can and should do with the savings thus achieved. Clearly, one possibility would be to lower all rates for electricity: the base sum charged customers regardless of their use or non-use of their pro-rata share of total capacity as well as the rate charged for eacli unit of electricity actually consunied. This is likely to be the only available response in states where the governing regulatory agency favors pricing by fully distributed costs-where price discrimination is disfavored and all consuniers must be charged the same price for the same product.

In states where marginal-cost pricing is permitted, another possibility would be to charge consumers in all-electric buildings a rate for their extra usage based only upon the marginal cost of supplying that extra electricity during off-peak months. Simce the amount of equipment employed by the company is determined almost solely by the summer's peak demand, the marginal cost of the added electricity in all-electric liomes would be very small, representing only short-run variable costs. This latter alternative, or some variation of it, is preferable to the former im the sense that it forwards the savings achieved by the employment of all-electric systems directly to those wliose actions produce the savings. Such allocation not only seems fair but also

75. All of the foregoing facts pertaining to the electrical industry were obtained from an interview with Austin R. Reed, Division Manager of Kansas Power \& Light Company, in Lawrence, Kansas, May 15, 1972. 
helps to induce more persons to go all-electric, thereby increasing efficiency in the operation. The Kansas Power and Light Coinpany uses such a system: it charges $\$ \mathrm{X}$ for each of the first $\mathrm{A}$ units of electricity, $\$ \mathrm{X}$ minus $\$ \mathrm{Y}$ for each of the next $\mathrm{B}$ units of electricity, and $\$ \mathrm{X}$ minus $\$ Y$ minus $\$ Z$ for each of the subsequent units consuned by an individual household. The breaking points- $\mathrm{A}$ and $\mathrm{B}$-are predetermined through einpirical studies, and both they and $X, Y$, and $Z$ will vary depending on whether the household is all-electric, minimally electric, or somewhere in between. ${ }^{78}$

A variation of this alternative would be to have a fixed rate per umit of electricity consumed and to give the buyer of the building a lump sum of cash reflecting the present discounted value of savings expected because the building is all-electric. But except to the extent that these schemes enter the builders' calculations of homebuyers' desires for gas or electricity, they will not induce non-owner builders to build all-electric buildings.

Another possibility would be to make the lump payinents directly to the builders and allow them to pass on the savings to the ultimate buyers in the form of lower prices on the buildings. This could benefit the builders in one of two ways. If a coinpetitive housing narket forces them to pass the savings on to buyers, they still are able to operate with a lower cash requirement during the construction period than would otherwise be possible, since the cash payment could be viewed as an extension of credit. Or, to the extent the housing inarket is non-competitive in a particular location at a particular time, they can increase their profits directly by keeping the cash payments rather than passing them on as lower prices.

Instead of making cash payments to the builders to induce thein to go all-electric, the electric coinpany could transfer something else of value-for example, wristwatches, golf balls, cases of soft-drinks, or free URD. Viewed in this manner, VEPCO's scheme might well be classified as an innocuous promotional practice which simply transfers to consuners something of value to which they are in fact entitled.

But three problems are raised by this type of scheme that are not raised by any of the foregoing ones. The first arises only if the electric company does not have a legitimate monopoly over the dehivery system. As I noted earlier, it is quite possible that VEPCO did not have a legitimate monopoly over URD and overhead line imstallation but had achieved its market position in these products by pricing thein below cost. The problem thus raised is that a promotional scheme which always, rather than for just a short introductory period, gives consumers

76. $I d$. 
a certain item for free harms producers and potential producers of that item by foreclosing a portion of the market. To the extent we wish to protect competitors, we might wish to forbid such a scheme. But it is interesting to note that if we do so, we are protecting not competitors in the electricity market but competitors who would otherwise provide URD. If, on the other hand, the electric company has a valid monopoly over URD, this first problem disappears, for then the gift of URD is tantamount to a cash transfer which harms no one.

But the second problem will still arise. There will be unjustified discrimination against consumers who go all-electric but for some reason reject URD in favor of overhead lines. They; too, contribute to the economies achieved; but if free URD rather than cash is given, and if they reject URD, they will receive none of the savimgs they created, even though their fellow all-electric users receive something of value. Indeed, carrying Fortner Enterprises v. United States Steel Corp. ${ }^{77}$ to its logical conclusion, this practice could be viewed as a tying arrangement in which the tying product is all-electric systems plus cash or credit and the tied product is URD.

The third and most serious problem goes to the heart of the allegation that VEPCO employed a scheme which forced builders to go all-electric. To make the plaintiff's case as strong as possible, assume that URD was a very highly desired service and that, in certain imstances, URD was required by local ordinances. Assume further that VEPCO had a monopoly over URD which was neither obtained nor maintained illegally. As the facts were stated by the court, VEPCO gave builders two basic choices: They could pay for URD, or they could go all-electric and get URD for free. Plaintiff contended that the scheme forced builders to go all-electric.

The contention is not necessarily correct. If the price paid by builders for URD when they chose not to go all-electric represented the actual cost of installing the underground system, builders paid a fair anount for the desired or required commodity. The plaintiff, Washington Gas Light Co., could hardly complain that VEPCO was acting unfairly by requiring consumers to pay for a product they purchased. Furthermore, to repeat my earlier point, if VEPCO had a valid monopoly over URD, providing URD for free to consumers who went all-electric could be viewed as a cash transfer of the economy-ofscale savings resulting from non-summer electricity consumption. As long as the price of URD did not exceed the present discounted value of the anticipated savings which would accrue annually, the scheme was as unassailable as a cash advance to the builders.

77. 394 U.S. 495 (1969). 
Furthermore, when the builder was also the owner and prospective user of the property, there was little ground for objecting to the practice. In such instances the builder-owner-user could be aware of the cost factors involved and balance them in his estimation of the relative worth of an all-electric system versus a minimum-electric system. The principal objection would be that when the builder-owner-user later sold the house, the relationship between him and his buyer would be akin to that of a non-owner-user builder and his buyer. The scheme must therefore be examined with that relationship in mind.

The scheine was not so innocuous when the builder was not the owner and prospective user of the building. Although it was still true that VEPCO was paying out only an amount which would soon be recovered (under the presently assumed state of facts), it was possible that in many instances the benefits did not reach the individuals who eventually paid the electric bills, but instead were retamed by the builders. Builders could not act in such a manner either in a perfectly competitive housing market or on a cost-plus contract by which a builder agrees to construct a building in return for payment of his costs plus some profit percentage by the owner. But even under costplus contracts the homebuyer might suffer, for often builders build for developers who then sell to the public. In those cases the developers could keep the benefits from the VEPCO scheine, and the buyer would still pay the bills.

In all the cases where the benefit did not accrue to the buyers, the builders' view of VEPCO's scheme was that if the builder went allelectric, VEPCO would pay him a lump sum of money, but if he went minimally electric, VEPCO would pay him nothing. When the facts are thus reduced for sunplicity, it is clear that whatever tie-in existed with respect to the builders imvolved cash as the tying product and the materials and services needed to go all-electric as the tied product. Unless Fortner is to be extended ad absurdum, VEPCO cannot be said to have had unique cash or power in the cash market; hence, there was no tie-in with respect to the builders.

\section{VEPCO and the Antitrust Laws: Abandoning Tie-in Analysis}

Since no tie-in existed between builders and VEPCO, one might consider extending traditional tie-in analysis so as to find a tie-in of some indirect sort imvolving prospective buyers, builders and VEPCO, perhaps on an agency or assunied agency primciple. But such an attempt would be both silly and unnecessary, a classic case of the tail wagging the dog. According to the courts, the antitrust laws are really concerned with protecting competition and competitors; the tie-in characterization is simply an analytical tool developed to facilitate analy- 
sis. When the tool is used for purposes for which it is not fit, it hinders rather than helps analysis. The appropriate question to consider at this point, therefore, is whether VEPCO's scheme violates the antitrust principles set forth in the Sherinan and Clayton Acts. ${ }^{78}$

Section 3 of the Clayton Act states:

That it shall be unlawful for any person engaged in commerce, in the course of such commerce, to lease or make a sale or contract for sale of goods, . . . supplies, or other commodities . . . for use, consumption, or resale .... or fix a price charged therefor, or discount from, or rebate upon, such price, on the condition, agreement, or understanding that the . . . purchaser thereof shall not use or deal in the goods, ... supplies, or other commodities of a competitor or competitors of the lessor or seller, where the effect of such lease, sale, or contract . . . may be to substantially lessen competition or tend to create a monopoly in any line of commerce. ${ }^{79}$

Three observations should be made about the statutory language. First, Congress expressly recognized that discounts on the sale of an item can serve anti-competitive as well as competitive ends and enabled the courts to declare illegal agreements which involved anticompetitive discounts. Second, Congress was concerned about the lessening of competition in any line of commerce. Finally, as noted earlier, the statute applies only to agreements which inhibit purchasers from dealing in the goods of the sellers' competitors.

Applying these observations to the VEPCO scheme, one notices that the scheine provided for a discount on the sale of an item in commerce: URD systems. Furthermore, competition was lessened in two markets-the market for energy for lome use and the market for home appliances-because the lump payments made to builders who were able to profit from the payinents rather than passing thein on to buyers induced builders to select gas or electric systems other than on the merits of the two products. If the savings resulting from allelectric systems had been passed on to consumers by VEPCO in the form of lower rates, builders trying to decide whether to go all-electric

78. The opinion in Fortner Enterprises is instructive on this point:

A preliminary error that should not pass unnoticed is the District Court's assumption that two prerequisites [for establishing a tie-in] mentioned in Northern Pacific are standards that petitioner must meet in order to prevail on the merits. On the contrary, these standards are necessary only to bring into play the doctrine of per se illegality. Where the standards were found satisfied in Northern Pacific, and in International Salt ... this Court approved summary judgment against the defendants but by no means implied that inability to satisfy these standards would be fatal to a plaintiff's case. A plaintiff can still prevail on the merits whenever he can prove, on the basis of a more thorough examination of the purposes and effects of the practices involved, that the general standards of the Sherman Act have been violated.

Id. at $499-500$.

79. 15 U.S.C. $§ 14$ (1970). 
would consider consumers' desires, taking into account various possible rate structures depending on the type of system installed. Because VEPCO induced builders to go all-electric, builders in effect agreed not to deal with the gas company, and sellers of gas-operated appliances were foreclosed froin competing with sellers of electrical appliances for a large portion of the market.

On the other hand, builders did not agree not to use or deal in the goods of VEPCO's competitor (unless VEPCO itself sold the equipment and services builders needed to go all-electric). The Clayton Act therefore cannot be applied to the VEPCO scheme. But the Sherman Act simply proscribes "[e]very contract . . . in restraint of trade." payment to builders who agreed to go all-electric, restrained trade without justification. To the extent that VEPCO wished to reduce the price of electricity to reflect the lower costs it incurred when buyers went all-electric, it could have done as Kansas Power and Light Company does: reduce electricity rates proportionately with the amount of electricity used for all-electric users. By employing a scheme which did not pass on the savings to many consumers, VEPCO vastly altered the competitive circumstances in two markets.

The lump sum scheme is undesirable for other reasons. First, it involves a mucli riskier estimate of the savings from the use of an all-electric system. Rather than passing on the savings as they occur in the form of lower rates, the electric company nust estimate what future savings will be. Since the use of electricity varies from allelectric household to all-electric household, some owners also will necessarily be discriminated against by uniform estimates.

Second, there is the problem inentioned earlier, that by allowing VEPCO to give away some item of value rather than cash, the risk of inbibiting potential competition in that market arises. Thus, VEPCO's "gift" of overhead lines and of URD may have had a stultifying effect on the inarket for those services. ${ }^{81}$

Finally, all of the foregoing objections apply to cases in which the price charged by VEPCO for URD did not exceed the anticipated savings to result froin all-electric use. In cases where that condition was not met, VEPCO was also engaging in the tactic of pricing at a

80. 15 U.S.C. $\$ 1$ (1970).

81. The adverse effect on desirable competition wrought by promotional practices has been expressly recognized by the National Association of Regulatory Utility Commissioners. In fact, that body has proposed that such practices be proscribed by all regulatory bodies. See National Association of Regulatory Utility Commissioners, Model State Commission Rules and Regulations Governing Promotional Practices of Electric and Gas Public Utilities \& $3(\mathrm{e})$ (Nov. 19, 1970). 
loss to those who purchased all-electric systems and, presumably, making up the losses through higher uniform rates to all customers. This type of discrimination against minimum-electric system owners would constitute a rather clear attempt to monopolize in violation of section two of the Sherman Act, as well as an unreasonable contract in restraint of trade in violation of section one. ${ }^{82}$

\section{CONCLUSION}

Antitrust cases are complex; the most fervent wishes and inysterious shibboleths will not alter that fact. Washington Gas Light Co. v. Virginia Electric \& Power Co. provides a classic illustration: The plaintiff's attorneys too quickly relied upon the talismanic "tie-in" because of its per se qualities, while the court too hastily relied upon the talismanic "single-product" defense without examining its function or the purpose of proscribing tie-ins. These fundamental errors were exacerbated by the failure of all involved to identify the relevant products.

Had the case been properly presented and analyzed, the court would have liad the opportunity to advance tie-in theory in several ways: (1) by showing that a single physical product can be viewed as two products for tie-m analysis even if for some uses it is viewed as a component of a single physical and antitrust product; (2) by showing that a simgle physical product can be viewed as two products for tie-in analysis when it has different functional uses; (3) by showing that a seemingly simple transaction can involve tie-ims of several types at several levels; (4) by showing that tie-ins do not require actual contractual promises in order to affect competition and competitors adversely; and (5) by showing that in defining markets it is imperative to distinguish unit sales based upon efficiencies from unit sales based upon inarket power. Finally, the court could have corrected soine particularly harmful promotional practices employed in the electrical industry.

82. There is a curious lack of agreement between the district court and the appellate court concerning the relationship between VEPCO's charge for URD and the added cost incurred by VEPCO by installing URD rather than overhead lines. The appellate court stated that VEPCO required builders to pay "the additional expenses involved, usually amounting to a sum around $\$ 280$ " when builders requested URD rather than overhead lines. 438 F.2d at 250 . The district court stated: "With the beginning of the 1963 plan the estimated charge for [URD] has been somewhat wide of the actual installation costs." 309 F. Supp. at 1122. A dispute over something as basic as this makes one quite wary of suggesting that the courts should try to determine the accuracy of a figure as speculative as the anticipated savings to result from all-electric use. 


\section{California Law Review}

\begin{tabular}{lll}
\hline VoL. 60 & NoVEMBER 1972 & No. 6 \\
\hline
\end{tabular}

\section{BOARD OF EDITORS}

Notes \& Comments

KEVIN F. KeLLY

WiLliam F. Capps

Craig H. Casebeer

MARK S. DODSON

ANN FIngaretTe Hasse

LESLIE ANN JOHNSON

CRAIG D. MILLER

JOHN E. THORSON

\section{Projects}

JEFFREX M. ALLEN

Joseph P. DICtuccio

Susan Frelich Appleton ALICE M. BEASLEY

MiChaEL J. BerTINETTI

Cerristopher C. Calkins

RAYMOND A. DIAZ

PAUL E. DORRoH

KENNETH J. FISHBACH JR.

JAMES A. ASKEW

RANDAIL IRA BARKAN

WIILIAM A. CARDWELL

Paut Clark

GARY JAY COHEN

RrChard DELGado

PhilIP R. DIAMond

Patricta D. Douglass

JOHN A. GLOGER

ROBERT A. GOODIN

DOUGLAS L. HAMMMER

JAMES E. HARTLEY

ROBERT M. JENKRNS III

MARTIN WAYNE JOHNSON

ELIOT S. JUBELIRER
Editor in Chief

STEPHEN L. KostKA

Managing Editor

STEPHEN JULIAN YODER

Managing

GabriELle R. CAMPBelL

JAMES DRUMMY

PETER GRossmaN

\section{Associate Editors}

ERNESTINE FORREST

HOWARD W. FOSS JR.

DAVID GOLDBERG

Kelly GUEsT

JACK $\mathrm{H}$. KaUfMAN JR.

LARY LAWRENCE

DANIEL J. LeER

Howard ALAN LATIN

ROBERT L. LAWRENCE

MICHAEI ROBERT LEVINE

MARY M. LOGALBO

PETER LOMHOFF

RANDALL, R. MCCATHREN

JULIE E. MCDONALD

PATRICIA ANN MAPpS

ALAN MItTMan

Lise A. Pearlman

LARRY PEITZMAN

JOSEPH P. POWERS

JAMES D. RICHMAN

GEORGE RUTHERGLEN

Administrative Assistant
Articles \& Book Reviews

IrA MARK ElLMAN

MTCHAEL J. BAKER

Marsha Siegel Berzon

DAVID F. BOYLE

Supreme Court

PaLMer Brown MADdeN

Research

SteVen S. Bell

RICHARD KaLISH

Camille E. LeGrand

Charles H. Matthews, Jr.

RAYMOND D. PIKE

Thomas E. RANKIN

Lee Charles Rosenthal

Craig M. Thomas

MARTIN J. ThOMPSON

SUSAN SAWYER

ChrISTOPHER H. SchrozdER

Thom Greenfirld Seaton

HENRY SHUELDS, JR.

SCOTT SONNE

NANCY E. SULLIVAN

E. ELIZABETH SUMMERS

ANNE MCLEOD TREpIICOCK

Catalna Valencia

DAVID L. WAGNER

ULRICH WAGNER

Patrick W. Warsh

ROBERT E. WIILETT

Thomas S. WIILIAMSON, JR.

DANIEL D. WOO 